\title{
Analysis of an Off-Grid Photovoltaic-Wind Hybrid Power System for Disi Water Pumping Project
}

\author{
S. Abdul-Rahman, A. Badran* \\ Mechanical Engineering Department, University of Jordan, Amman, 11942 Jordan
}

\begin{abstract}
A standalone hybrid PV/ wind energy system is proposed to be used to continuously power a submersible water pump from a selected well out of 55 production wells located at the Disi aquifer, South of Jordan. Each of these wells has a continuously-operating water flow rate of $288 \mathrm{~m}^{3} / \mathrm{h}$. Excess energy, if any, is to be stored in the form of a pumped water storage at the ground level near the well. Solar radiation and wind speed data for Al-Mudawara border meteorologicalstation, which was taken as a representative of the Disi water aquifer were collected and analyzed. Energy analysis was monthly made on the basis of average daily available energy. The performance of three PV/wind power plant scenarios was analyzed through the study of the underground water pumping wells using Life Cycle Cost (LCC) method. It was found that, for one scenario, the hybridization of a $16.5 \mathrm{MW}$ is produced by PV power plant and 27.5 MW by wind power plant at Al-Mudawara site is the optimal scenario which is economically and technically feasible. It was found that the storage energy covered the load after implementation of the proposed project, the cost of $1 \mathrm{kWh}$ of energy produced was estimated to be $0.16 \$ / \mathrm{kWh}$., and the system payback period was 4.5 years.
\end{abstract}

Keywords: Hybrid system, Off- Grid, Storage tank.

\section{Introduction}

Disi is a water aquifer stretching from the Southern edge of the Dead Sea in Jordan to Tabuk in Northwest borders of Saudi Arabia. Figure 1 shows the topographical map of Jordan, where Al-Mudawara is at its Southern tip.

Significant exploitation of the Jordanian side of the aquifer with a stable upper layer and scattered scabs started in 1980. At present, Aqaba city is supplied with 16.5 MCM for domestic purposes and $75 \mathrm{MCM}$ for agricultural purposes. Saudi Arabia develops around 4 BCM yearly and uses it for irrigationpurposes. The wind turbine was installed at one of the water wells in the Disi aquifer, at the Jordan-Saudi Arabia border, as a replacement for a diesel engine driven vertical shaft pump [1]. The pump has been operated since then, with only minor maintenance routines and is extracting a sufficient quantity of drinking water to theborder check point and the local Bedouins.

${ }^{*}$ Corresponding author. Tel.: 00962785413649

E-mail: badran@ju.edu.jo

(C) 2017 International Association for Sharing Knowledge and Sustainability

DOI: $10.5383 /$ ijtee.14.01.006
A PV-Wind hybrid system was proposed to produce enough energy to drive existing pumping systems in the Disi. In addition, extra energy will be used to store pumped water at ground level at the same location. One typical water well at power demad of $250 \mathrm{~kW}$ was selected to be provided with the required energy in this work. Qandil[2]designed an off-grid PV system that supplies required energy for Disi water pumping from that field to Amman. He assumed a continuous flow of 80 Liter/s per well, and found that the power required for the system was about $13.75 \mathrm{MW}$. Matthias[3] evaluated the financial feasibility of PV-Wind hybrid system installed in Germany. He found that the decentralized pumped storage hydropower plants remained the most efficient option to store electricity surplus from intermittent sources. The pumped storage plant can adapt the frequency of the grid when the load changes within a short period of time. Dihrab et al [4] were the first to discuss the feasibility of using hybrid PV-Wind system in Jordan. They discussed providing four cities with electrical energy but their system was grid connected and did not contain any storage features. They indicated that the location can be affected by the output energy of the wind turbine. Abu-Aligah [5] made a comparison between photovoltaic water pumping 
and diesel powered pumping. He found that the maintenance and life-time running cost of a PV system are negligible compared to those of the conventional energy systems such as diesel. The initial cost of a PV system is significantly higher but the operation cost is much lower.

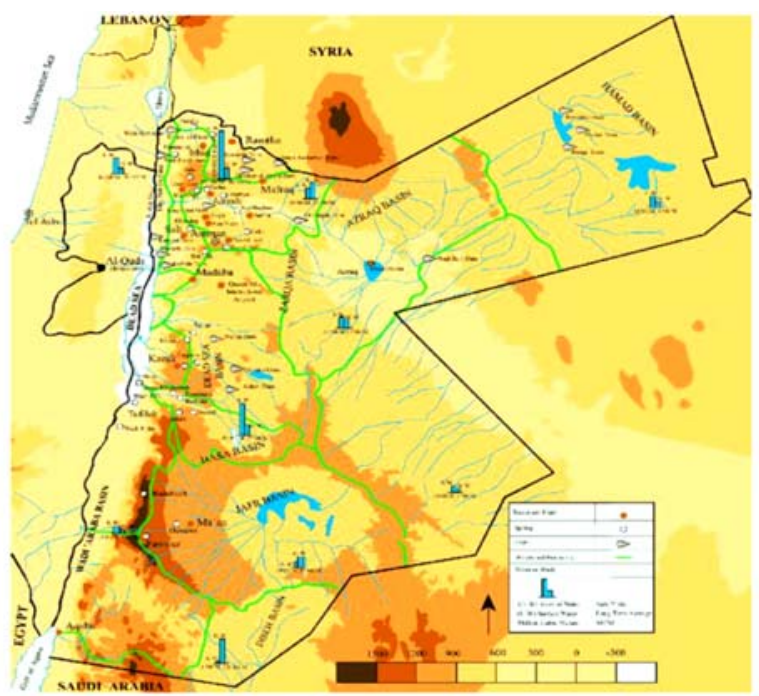

Figure 1. Jordan's topographical map

Ismail et al [6] proposed a case study of optimizing different types of hybrid systems (PV-Wind, wind-diesel, Storage Battery and Diesel Generator) to supply a load in Nablus and Ramallah sites in Palestine. They found that the best solution to choose the appropriate size of various components for the most optimum scenario is based on the cost of generation. They also found that the PV-Wind, diesel with storage battery hybrid system was the best scenario.

In this work, a hybrid system (PV and wind) was proposed for Disi water pumping project, located near Al-Muawara border post south of Jordan (latitude $29^{\circ} 12^{\prime} \mathrm{N}$ ) as an appropriate system that utilizes renewable energy resources as well as energy storage features in Jordan. The system consists of 55 wells that consume about $44 \mathrm{MW}$. One typical well was selected which consumes $300 \mathrm{~kW}$ of PV power and $500 \mathrm{~kW}$ of wind turbine power.

\section{Water in Jordan}

In terms of water available to each citizen, Jordan is considered one of the driest ten countries in the world. Already scarce water resources will soon be even thinner, with the population predicted to double in less than 25 years. Jordan's thriving population drives the demand for water, but it additionally promotes unregulated development, which pollutes the groundwater on which people depend. Most of the increase in the area of irrigated land in the world was dueto theincreasing use of engine-driven pumps. However, the increasing price of oil-based fuel has reduced the margin gained by farmers from irrigation, since it was generally prevented to raise food prices in line with energy costs. Despite the present short-term fluctuations in oil prices, conventional oil-based engine-driven power sources and electricity mains are expected to keep onto increase in the long term. If Jordan chose to downgrade their dependence on imported oil, they will have to find methods for energizing irrigation pumps that are independent of imported oil or centralized electricity. Solar radiation as a source of energy is, of course, the symbol of the clean and sustainable energy technology, except for residues, possibly arising from the manufacture of solar component (e.g semiconductors). Solar technology has very low environmental impacts. The environmental impacts of solar system in operation are very low and the source is, for us, renewable and inexhaustible. The Ministry of Water and Irrigation (MWI) is concerned looking at the potential options of generating renewable energy to serve reduce the cost of electricity that should cover the water sector. The aim of this study is to find the basic economic figures to make a decision for the future electricity supply for the water sector as well as to prepare for the related regulatory negotiations between the Ministry of Water \& Irrigation and the National Electric Power Company (NEPCO), and the Jordan electric distribution companies. This study was conducted by a joint team of MWI, GIZ and Jordan Chamber of Industry (JCI). In the preparation sessions, the scope of the study was stretched to include wind turbine options. The study assumed an overall water use in Jordan of 1 Billion $\mathrm{m}^{3} / \mathrm{year}$, while the annual consumption of electricity for water supply is $1939 \mathrm{GWh} / \mathrm{y}$ (2011) [7]. Thus the overall average specific electricity demand for water supply is $1.9 \mathrm{kWh} / \mathrm{m}^{3}[7]$.

The electricity tariff for the water sector has been changed in 2013, where the fee for $\mathrm{kWh}$ is to increase annually, from 76 fils in 2013 to 133 fils in 2017, (\$1.0 $\approx 700$ fils)as shown in Table 1 . Thus in 2017, the electricity bill for water supply in Jordan will rise to a total amount of 258 Million JD assuming the amount of water consumption is situated at 1 billion $\mathrm{m}^{3}$ (which is very unlikely)[7]. After 2017, one should assume an annual rise of at least $2 \%$ in the electricity tariff. The costs above do not include the power demand of the Disi Water Conveyance project; where it is estimated (based on the WAJ data for 2013) that each $1 \mathrm{~m}^{3}$ requires about $2.8 \mathrm{kWh}$, i.e. for $100 \mathrm{MCM}$ the energy demand will be $280 \mathrm{GWh}$ resulting in a cost of around 24 million JOD in 2014 [7]. These calculations make it imperative for MWI to consider renewable energy sources to decline the burden of electricity costs on the water sector. The study mainly considered solar energy generation potentials; it also includes wind energy where appropriate. Concentrated solar power is not further examined as it seems to be not economically viable under the current and conditions. The study offers an overall analysis i.e. with a vision to cover the total demand for electricity and also provides analysis for covering a modular approach: [7].

Table 1.Tariff summary of electrical energy for water pumping plants and sewage treatment plants owned by Water Authority all over the Kingdom

\begin{tabular}{|l|c|c|c|c|c|}
\hline Unit & $\begin{array}{l}15 / 8 / 2013 \text { to } \\
31 / 12 / 2013\end{array}$ & 2014 & 2015 & 2016 & 2017 \\
\hline $\begin{array}{l}\text { Fils for } \\
\text { each } \\
\text { kWh } \\
\text { sold }\end{array}$ & 76 & 87 & 100 & 115 & 133 \\
\hline
\end{tabular}

\section{Renewable Energy Water Generation Based Scenario}

Electrical power generation in Jordan depends predominantly on fossil fuels, which have significant impact on environment by emitting harmful greenhouse gases (GHG) such as $\mathrm{CO}_{2}$ and NOx. Power generation in 2013 achieved to around 17,261 Gwh, which corresponds to more than 15 million tons of $\mathrm{CO} 2$ 
emissions. That is the real challenge is apparently added for the country. It advises switching to renewable energy and clean power generation systems to contribute to protect the local environment. If MWI is to consider a long term vision of generating all the electricity it consumes for water supply from alternative renewable resources, a total amount of about 1900 $\mathrm{GWh} / \mathrm{y}$ has to be generated, assuming a supply of 1 billion $\mathrm{m}^{3}$. The investment for an overall renewable energy solution (combination of wind and photovoltaic) would be given an estimate of about 1.3 Billion JOD [12]. In order to finance this solution, the principal payments, the interest and the maintenance cost would lead to yearly payments of about 150 million JOD per year over 20 years. As Figure 2 shows, the renewable energy system (RES) will be very attractive. The scenario of generating the entire consumption of electricity by renewable energy would yield in saving, in average, 144 million JOD per year for the life of the system (20 years) assuming an increase of $2 \%$ in tariff beyond 2017. If the tariff after 2017 stays constant at $133 \mathrm{fils} / \mathrm{kWh}$, the savings will be around 100 million JOD per year over the total life span of the system.

\section{opportunity cost tariff / renewable energy (JD)}

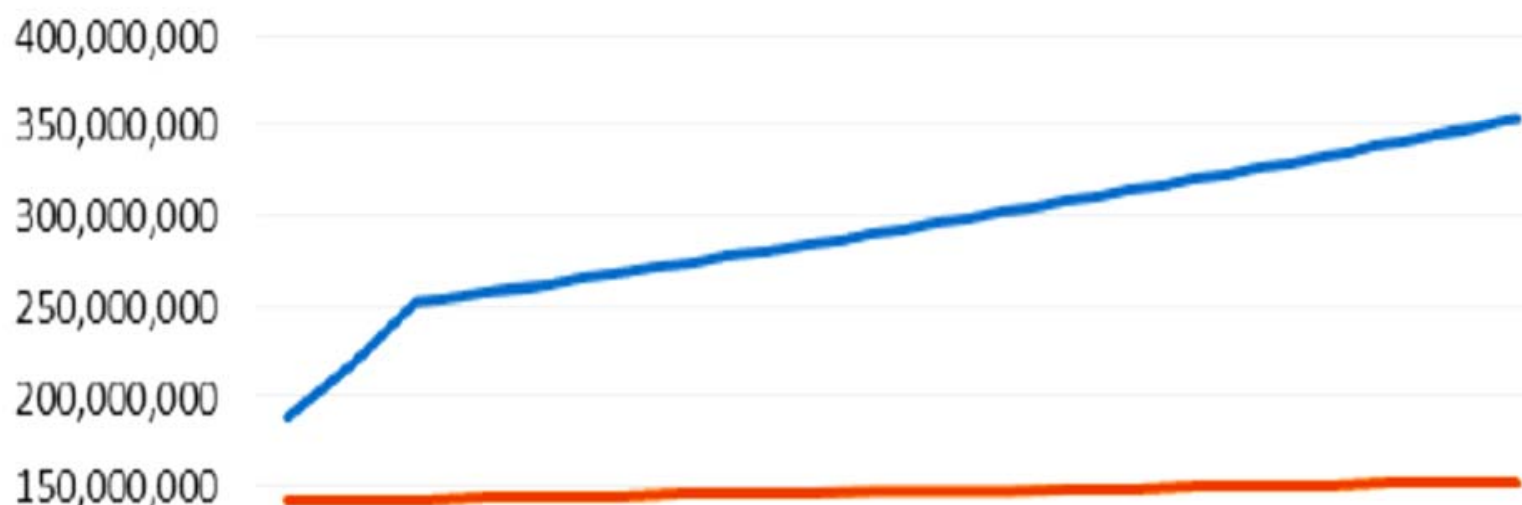

$100,000,000$

$50,000,000$

0

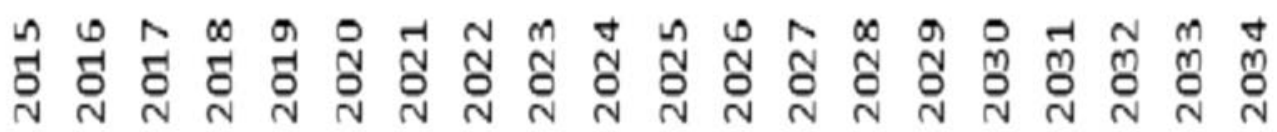 \\ electricity Bill $\quad$ RES cost}

Figure 2.Comparison of conventional electricity consumption costs with renewables (wind and PV)

The above figures are based on the assumption of a decentralized solution for direct electricity consumption at the demand centers. That is installing a number of solar power generation plants where pumping stations and centers would cause additional costs.

\section{Mathematical Model}

\subsection{PV module}

A photovoltaic cell is a non-mechanical device usually made from silicon alloys. Photovoltaic cells, like batteries, generate direct current (DC) which is generally used for small loads (electronic equipment). The following equation calculates that the number of module poly crystalline silicon cell type according toDuffie and Beckman [13] as:

Number of modules $=$ Ac/module area $=275,401$

Where Ac is the land area and the module area is based on the poly crystalline silicon cell type that commercially is available and is at $1.64 \mathrm{~m}^{2}$.Therefore, the crystalline silicon modules may be arranged in columns and rows, and those modules may be distributed over the total area of PV array in 19 columns and 8rows for each well.

The total spacing between module rows can be evaluated according to eq. 2 as: 
$\mathrm{Y}=1{ }^{\prime}+\mathrm{S}=4.68 \mathrm{~m}$

Where

$S=h / \tan \alpha s=2.84 \mathrm{~m}$. and

The total spacing between module rows

$\mathrm{Y}=1$ '' $+\mathrm{S}=4.06 \mathrm{~m}$

Now, the land area considering the effect of shading on cell performance may be found as follows:

Land area $=[(Y+$ module thickness $) *$ No.of rows $] *$ width of all module in each row]

Land area $=234.11 \mathrm{~m}^{2}$.

The area for offices, substations ...etc.centers would cause additional costs. If options for electricity or energy storage are to be included,this would necessitate further costs.

\subsection{Inverter Selection}

For selecting an appropriate inverter, three main factors should be taken into account; its output $\mathrm{AC}$ power, the dc-ac conversion efficiency and capital cost. Regarding the AC power output, the maximum electrical power needed by the submersible pump to elevate water from well was taken at the worst case condition. The second factor for inverter selection is the conversion efficiency from DC power to ac if the inverter is more efficient the battery bank will not be smaller(but the battery will not be used in this plant). To be considered the ac load matched to the suggested inverter and the inverters size in term of power output, is aidmaximization efficiency level. invertermanufacturers list the efficiencies of their units on all of their specification sheets, which usually contain two values, one is called the peak efficiency $\eta_{\text {inv,p }}$, and the other more reliable value is called the CEC weighted efficiency

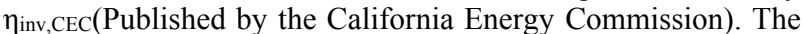
capital cost of inverters, the third factor, differs widely due to the power size, efficiency, reliability and brand. Searching for the most suitable inverter brand requires taking in mind the basic demands of the required inverter. When sizing the inverter for a PV system, the actual power drawn from the PV array must be determined, the inverter power is equal to 33000 W with $97 \%$ efficiency.

\subsection{Wind Turbine}

The energy that can be converted by wind turbines to electrical energy is highly dependent on the local average wind speed.

The amount of power transferred to a wind turbine is directly proportional to the area swept out by the rotor, to the density of the air, and the cube of the wind speed and given by

$$
P=0.5 \rho V^{3}
$$

The technical specification of the wind turbine used in the studied project are given in Table 2.

Table 2. Wind turbine specifications (Vestas V39, $500 \mathrm{~kW}$ )

\begin{tabular}{|c|c|c|c|}
\hline $\begin{array}{l}\text { Peak power } \\
(\mathrm{kW})\end{array}$ & $\begin{array}{l}\text { Swept area } \\
\left(\mathrm{m}^{2}\right)\end{array}$ & $\begin{array}{l}\text { Rotor diameter } \\
(\mathrm{m})\end{array}$ & $\begin{array}{l}\text { Hub height } \\
(\mathrm{m})\end{array}$ \\
\hline 500 & 1195 & 39 & 53 \\
\hline
\end{tabular}

The availability factor, $\mathrm{AF}$, is the amount of time that a power plant is able to produce electricity over a certain period of time divided by the amount of the total time available in that period. For wind turbines, the availability is calculated through deducting the time intervals that the speed of the wind is lower than cut-in or higher than cut-out speeds of the wind turbines.

$$
A F=1-(n / N)
$$

Where: $n$ : is the number of months when the wind speed is lower than the specified cut-in speed $(<4.0 \mathrm{~m} / \mathrm{s})$

$N$ : is the total number of months.

$\mathrm{AF}=1-(125 / 300)=58.33 \%$

Wind turbine efficiencies depend on many factors, especially its design, shape and other characteristics. Equation 4 is used to evaluate maximum theoretical wind turbine efficiency [14].

$$
\eta_{\max }=\left[1 / 4 \rho A\left(V_{i n}+1 / 3 V_{i n}\right)\left(V^{2}{ }_{i n}-\left(1 / 3 V_{i n}\right)^{2}\right)\right] /\left[1 / 2 \rho A V^{3}{ }_{i n}\right]
$$

Where $\eta_{\max }$ is the maximum theoretical wind turbine efficiency, $V_{i n}$ is the entering wind speed, $A$ is the swept area and $\rho$ is the air density.

Hence

$\eta_{\max }=\left[1 / 4 \rho A(4 / 3 \operatorname{Vin})\left(8 / 9 V_{\text {in }}{ }^{2}\right)\right] /\left[1 / 2 \rho A V^{3}\right.$ in $]=16 / 27$

$$
=59.6 \% \text {. }
$$

This means, it is no more extraction than $59.6 \%$ of available power in wind.

\section{Metrological data}

Al-Mudawara has annual global radiation of $2300 \mathrm{kWh} / \mathrm{m}^{2}$, and annual average wind speed of $7.6 \mathrm{~m} / \mathrm{s}$. the real data for solar radiation and wind speed were measured at the Al-Mudawara site by National Energy Research Center at the Royal Scientific Society(nerc), per ten minute over one year, then a monthly average daily radiation wind speed were computed. Table 3 showsthemonthly average daily radiation and wind speed for Al-Mudawara.

Table 3. Monthly avg. daily solar and wind power of Al-Mudawara

\begin{tabular}{|l|l|l|}
\hline Month & \multicolumn{1}{|c|}{$\begin{array}{c}\text { Daily radiation } \\
\left(\mathbf{k W h} / \mathrm{m}^{2} \text { day }\right)\end{array}$} & $\begin{array}{c}\text { Wind speed at height } 53 \mathrm{~m} \\
(\mathrm{~m} / \mathrm{s})\end{array}$ \\
\hline January & 4.204 & 6.94 \\
\hline February & 5.089 & 8.62 \\
\hline March & 6.235 & 8.56 \\
\hline April & 6.939 & 8.01 \\
\hline May & 7.735 & 8.00 \\
\hline June & 8.537 & 9.15 \\
\hline July & 8.287 & 8.76 \\
\hline August & 7.752 & 8.72 \\
\hline September & 6.860 & 8.01 \\
\hline October & 5.265 & 6.29 \\
\hline November & 4.485 & 6.51 \\
\hline December & 3.786 & 6.31 \\
\hline
\end{tabular}


The storage power can be calculated as follows:

Storage power $=($ solar power + wind power $)-$ load.

Figure 3 shows monthly daily solar, wind and storage power of Al-Mudawara

\section{Storage Tank}

The required tank to store the pumping water for four hours is sized with capacity of $5000 \mathrm{~m}^{3}$. The storage tank dimensions is $24 \mathrm{~m}$ diameter and $12 \mathrm{~m}$ height. It is made of steel (Al-Nazir) [15] . In this paper, the required pumping power is supplied by the storage energy of hybrid system to store in the tank. The total pumping water capacity was calculated as the following (Sahin et al) [16]:

$\mathrm{Q} t=\mathrm{Pt} / \mathrm{H} \rho \mathrm{g}$

Where:

$\mathrm{P}$ : is the pumping water power which is supplied by the storage energy of hybrid system (W).

$\mathrm{t}$ : is the given period time (hour).

$\rho:$ is the density of water $\left(1000 \mathrm{~kg} / \mathrm{m}^{3}\right)$.

$\mathrm{G}$ : is the gravitational acceleration $(9.8 \mathrm{~m} / \mathrm{s} 2)$.

$\mathrm{H}:$ is thetotal head $(\mathrm{m})$.

Q:is the volumetric flow rate of water $\left(\mathrm{m}^{3} / \mathrm{s}\right)$.

$Q \mathbf{t}=9800 \times 10^{6} / 200 * 1000 * 9.8=5000 \mathrm{~m}^{3}$

\section{Results and Discussion}

Economical analysis is given for the proposed hybrid system. Three scenarios are estimated for the cost of the plant, the first of which is that the plant is at full operating capacity by wind power plant, i.e. the system produce $27.5 \mathrm{MW}$ capacity. The second would be that the plant is at full operating capacity by PV power plant, i.e. the system produce $22 \mathrm{MW}$ capacity. The final scenario would be that both systems would share $44 \mathrm{MW}$, i.e. 27.5 MW produced by wind power plant and $16.5 \mathrm{MW}$ by PV power plant. For each scenario, the Life Cycle Cost (LCC) method was used in order to find the payback period for the proposed system. Life Cycle Cost (LLC) is the total cost of purchase and operation of a project over its entire service life. Total cost includes the costs of acquisition, operation, maintenance and disposal.(Capehartet al 2006).

The LCC method here uses the Present Worth Value (P), which permits a comparing alternatives with different cash flows taking place at different times. For purposes of conducting an economical analysis, Future worth (F) must be calculated taking into consideration the P. A sum of money has to be changed over from its value in one time period to its equivalent value in another time period which is the time of payback period. The formulas and compounded interest rates are assumed to be compounded annually, while cash flows are assumed to be at the end of the year. The PWVof total costs for each alternative is calculated, and the alternative scenario with the lowest LCC will be selected. Accordingly, a payback period for each scenario is predicted. The benefit/cost ratio is then calculated, thus, determining the feasibility of the scenario. This work follows the outlined economical analysis procedure and is presented.

In order to find $\mathrm{F}$, the final worth of principal given that Pis known:

$$
F=P(1+i)^{n}
$$

Where:

$i$ : is the annual interest rate or discount rate, and now it is assumed to be $9 \%$; this may also be referred to as the minimum attractive rate of return or MARR).

$n$ : is the number of annual interest periods, usually in years, and for this project it is 20 years.

$P$ : is the present value (or present worth).

To find $A$, given that $F$ is known

$A=F[i /((1+i) n-1)]$

$A$ : is a single payment from series of $n$ equal annual payments that is required for the investment to break even after $n$ years. $F$ : is the future value (or future worth)

After $n$ years period of time, this work should reach point of breakeven where all costs spent is returned back to the investor. To find breakeven period knowing that the future value of initial investment equals the future value of periodic saving, we use the following equation written in the form below:

$$
F(1+i)-n=A[(1+i) n-1 / i]
$$

The Benefit/Cost Ratio, This ratio calculates the present worth of all benefits, calculates the present worth of all costs, and then takes the ratio of the two amounts.

$$
B / C=\text { Equivalent Benefits/Equivalent costs }
$$

Since the ratio came to be greater than 1 , the project is economically feasible.

Figure 4 and Table 4 illustrate the comparison between all scenarios. 

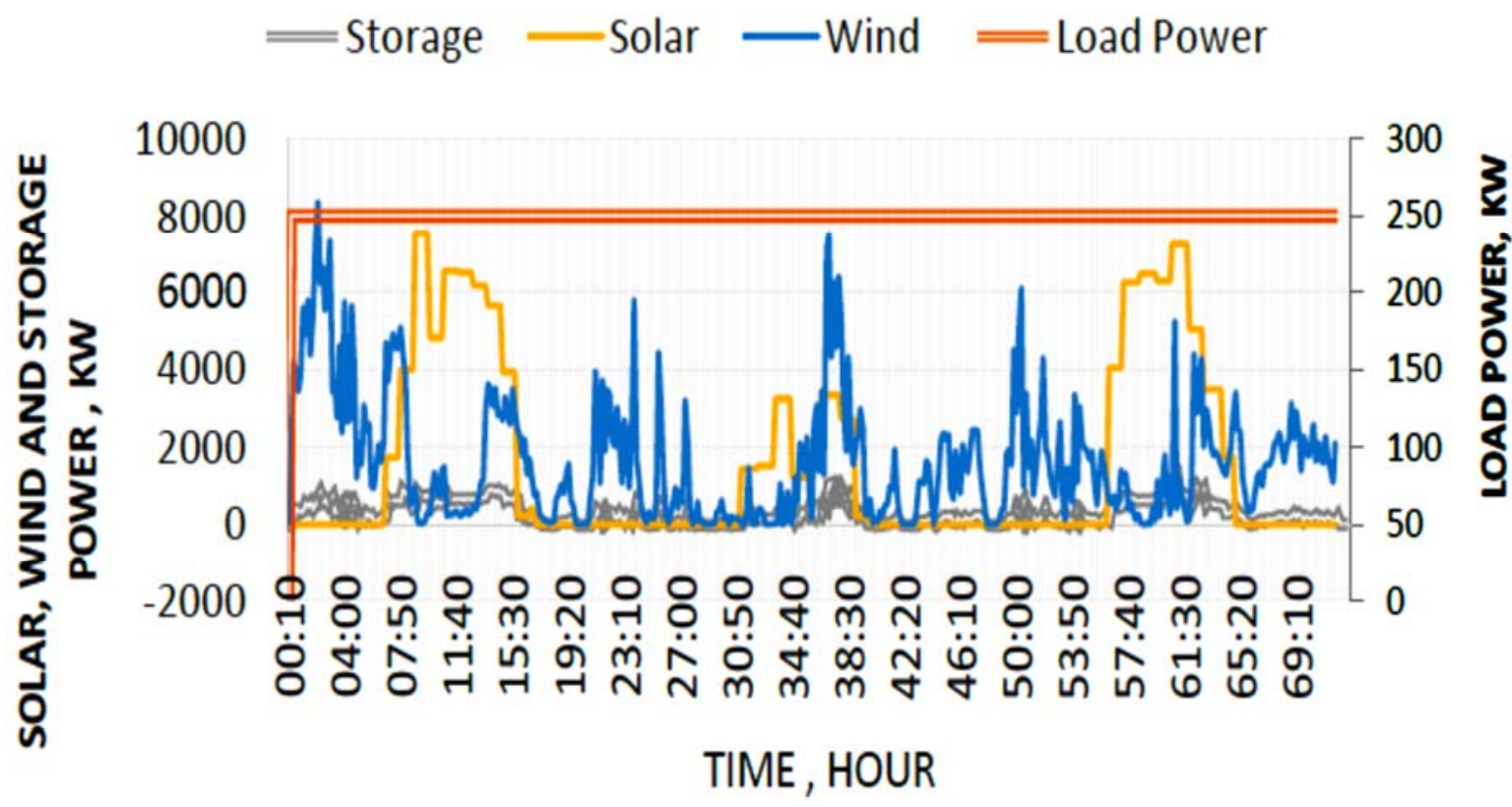

Figure 3. Monthly avg. daily solar, wind and storage power of Al-Mudawara

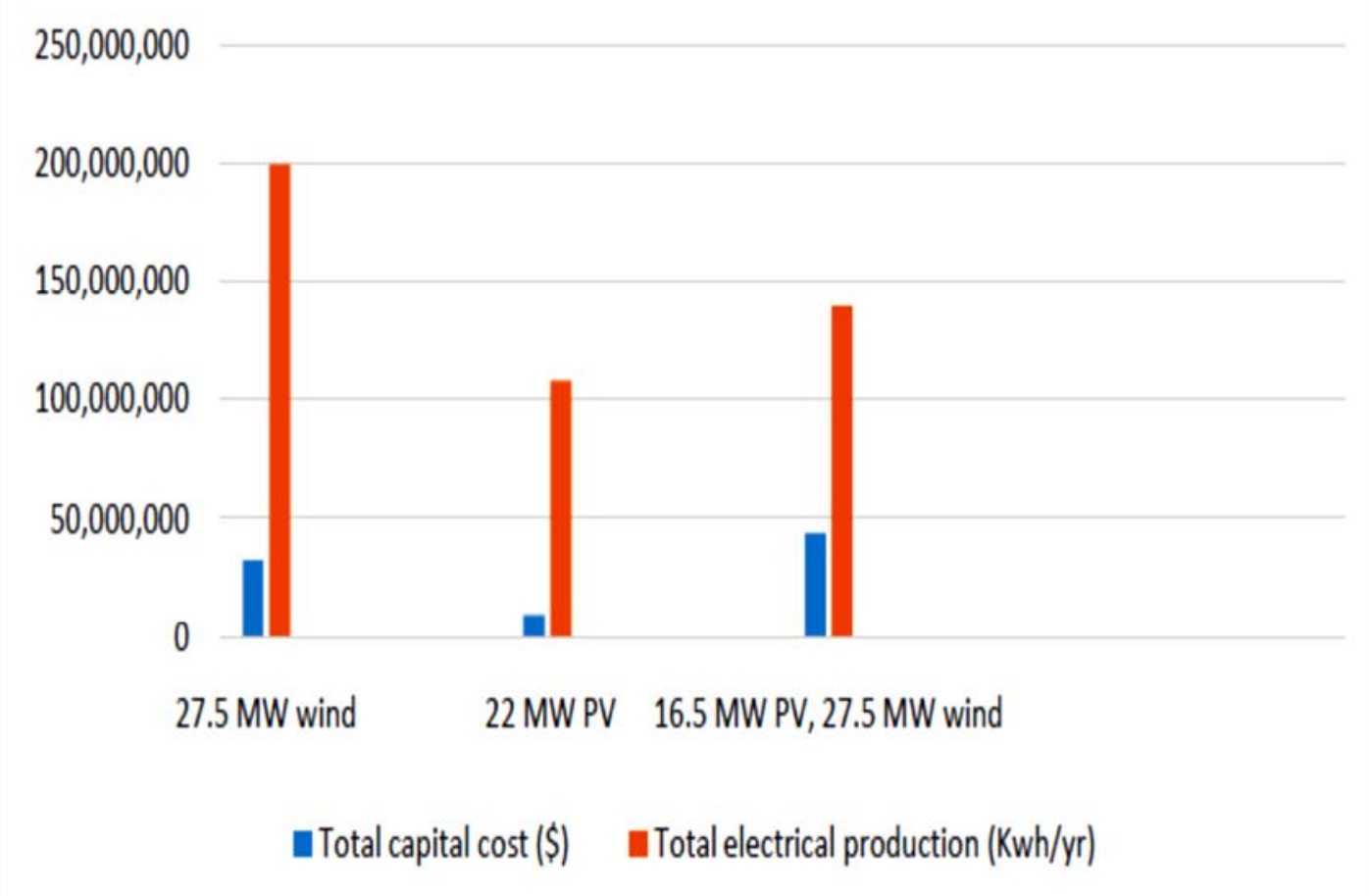

Figure 4.Comparison between all scenarios 
Table 4. Comparison between all Scenarios

\begin{tabular}{|c|c|c|c|c|c|c|c|}
\hline $\begin{array}{c}\text { Type of } \\
\text { power plant }\end{array}$ & $\begin{array}{c}\text { Total } \\
\text { capital } \\
\text { cost } \\
\text { (\$) }\end{array}$ & $\begin{array}{c}\text { COE } \\
\text { (\$\$/kWh) }\end{array}$ & $\begin{array}{c}\text { Wind } \\
\text { production } \\
\text { (kWhyr) }\end{array}$ & $\begin{array}{c}\text { PV } \\
\text { production } \\
\text { (kWh/yr) }\end{array}$ & $\begin{array}{l}\text { Brake- } \\
\text { cren } \\
\text { period } \\
\text { (yr) }\end{array}$ & $\begin{array}{c}\text { Benefit } \\
\text { Cost } \\
\text { Ratio }\end{array}$ & $\begin{array}{c}\text { Total } \\
\text { clectrical } \\
\text { produedion } \\
\text { (kWh/yr) }\end{array}$ \\
\hline $\begin{array}{l}27.5 \mathrm{MW} \\
\text { wind }\end{array}$ & $32,708.950$ & 0.3 & $110,547,376$ & - & 4.6 & 2.5 & $110,547,376$ \\
\hline $\begin{array}{l}22 \mathrm{MW} \\
\mathrm{PV}\end{array}$ & $9,648,671$ & 0.206 & - & $46,794,560$ & 6 & 2 & $46,794,560$ \\
\hline $\begin{array}{l}16.5 \mathrm{MW} \\
\text { PV, } 27.5 \\
\text { MW wind }\end{array}$ & $44,171,644$ & 0.085 & $110,547,376$ & $35,095,536$ & 4.5 & 4 & $145,642,882$ \\
\hline
\end{tabular}

The yearly amount of electrical energy generated from a 16.5 MW PV/ 27.5 MW wind plant at the site was estimated to be about $145,642,882 \mathrm{kWh}$. That is possible to couple photovoltaic and wind together to produce a large-scale of electric energy in rare area and reduce the imports of energy needed to cover energy demand in Jordan.

\section{Conclusion}

In this article, a hybrid system comprising solar energy and wind energy, namely PV modules and wind turbine is proposed inDisi (Al-Mudawara) in Jordan to be one of the renewable based future systems in Jordan.The proposed system is off-grid connected system able to feed the water pumping system with the electric power requirement. The hybrid system compose of $300 \mathrm{~kW}$ PV modules and 500 wind turbines for each well. The results shows that the power output fromAl-Mudawara (which is part of Disi water well project) was found to have a high potential of solar and wind energy. From this study it can be concluded that the choice of the plant location can strongly affect the plant performance. Polycrystalline silicon modules, suited on a tilt angle of $29.1^{\circ}$ rack structure was the suggested system configuration for the site in Al-Mudawara due to its promising incident solar radiation characteristics, which was resulting the huge energy from solar radiation around the year. It was also found that a steel storage tank of $5000 \mathrm{~m}^{3}$ capacity was capable of storing water pumped from the well at the ground level and the pay pack period was found about 6.2 years which is feasible for this investment and the benefit to cost ratio was about 1.6.

\section{Nomenclature}

D Diameter of the turbine's rotor , $m$

$\mathrm{A}_{\mathrm{c}} \quad$ Land area, $\mathrm{m}^{2}$

GIZ Deutsche Gesellschaftfuer Internationale Zusammenarbeit

Greek Symbols
As Angle made by the projection of a direct solar beam and southern direction, ${ }^{\circ}$

\section{References}

[1] BadranO,Wind Energy Research and Development in Jordan,Renewable Energy Congress VI, pp 2360-2368, 2000 .

[2] Qandil H, Solar Underground Water Pumping for DisiMudawarah Project Wells through the use of PV Panels, Master thesis, University of Jordan 2012.

[3] Matthias B, Hybrid Energy Production, Financial feasibility of a combined Solar/Wind Pumped Storage Hydropower System, The IMRE Journal 2013; 7.

[4] Diaf S, Diaf D, Belhamel M, Haddadi M, Louche A, A Methodology for Optimal Sizing of Autonomous Hybrid PV/Wind System, Energy Policy 2007; 35:5708-5718.

[5] Abu-Aligah M, Design of Photovoltaic Water Pumping System and Compare it with Diesel Powered Pump, Jordan Journal of Mechanical and Industrial Engineering 2011; 5 .

[6] Ismail M, Mahmoud M, Simulation of a Hybrid Power System Consisting of Wind Turbine, PV, Storage Battery and Diesel Generator: Design, Optimization and Economical Evaluation, Proceedings of the Global Conference on Renewables and Energy Efficiency for Desert Regions, (GCREEDER ), Amman, Jordan 2011.

[7] Ministry of Water and Irrigation, Options for Renewable Energy Projects in Jordan's Water Sector Report, pp 3-4, 2012.

[8] Duffie, Beckman. Solar Engineering Of Thermal Processes John Wiley \&Sons,INC., 1991.

[9] El-Wakil, M.M., Power plants technology, McGraw-Hill Inc 1984. 
[10] Nazir Z, Jordan Petroleum Refinery Co., Private communication 2015.

[11] Sahin A, Shafiqur R, Economical Feasibility of Utilizing Photovoltaic for Water Pumping in Saudi Arabia, Journal of Photo energy 2012; 9.
[12] AlHiaryL, Thermo Economic Analysis for a GridConnected Photovoltaic-Wind Hybrid Power Plant in Jordan, Unpublished master's thesis, University of Jordan, Amman, Jordan 2015. 